\title{
INVITRO ANTIMICROBIAL SUSCEPTIBILITY PATTERN OF BACTERIAL ISOLATES FROM WOUND INFECTIONS IN UNIVERSITY OF ILORIN TEACHING HOSPITAL
}

\author{
"TAMO S.S., 2 OKESINA A.B., 'ONILE BA. \\ *Department of Microbiology and Parasitology. ${ }^{2}$ Department of Chemical Pathology and Immunology \\ University of llorin Teaching Hospital, P.M.B. 1459, llorin, Nigeria.
}

\begin{abstract}
The outcome of 532 wound swabs received from patients with wound infections in different units of the University of llorin Teaching Hospital llorin, Nigeria, over a one year period (July 2000-June 2001), and routinely procesed by Gram staining and culture in the Mifrobiology Laboratory, is reported. 444(83.5) of all samples cultured positive for bacterial pathogens while $88(16.5 \%)$ were bacteriologically sterile. 272 swabs yielded single isolate whlle 172 yidided a mixture of two or more organisms. Staphylococcus aureus predominates (35.8\%), followed by Pseudomonas spp (21.8\%), Escherichia coll (15.3\%), Klebsiella spp (13.4\%), Proteus spp (5.6\%), Coagulase Negative Staphylococci (3.1\%), Streptococcus faecalis (2.8\%), Streptococcs pyogenes (0.9\%), Group B $\beta$-haemolytic Streptococci (0.9\%), and Acinetobacter spp (0.3\%).

Both Gram-positive and Gram-negative organisms demonstrated moderate to high in vitro sensitivity to Onoxacin and Ciprofloxacin (sensitivity rate 70-94\%). In vitro sensitivity to Cloxacillin, Erythromycin, Azithromycin and Ceftazidime by Gram positive organisms ranged beween 55 and $90 \%$ while Gentamicin, Ceftrazidime and Azithromycin equally demonstrated moderate to high inhibitory effect on Gram negative organisms including Pseudomonąs spp. (serisitivity rate $55-90 \%$ ).

The Fluoroquino lones are the favoured aritimicrobial agents nowadays, as demonstrated in this study. In out environment however, a combination of Cloxacillin and Gentamicin is an effective empiric alternative when cost is considered and this combination can be used. The need for continuous antimicrobial monitoring of clinical isolates of wound infection for drug resistance, which is of paramount importance in the empiric selection of antibiotics, is emphasized.
\end{abstract}

\section{INTRODUCTION}

Every individual carries a large resident microbial population on the skin surfaces, and in the openings of the hair follicles, sweat glands and sebaceous glands. This population comprises mainly Gram positive cocci of the genera Staphylococcus and Micrococcus, and Gram positive rods of the genera Propionibacterium and Corynebacterium together with the yeast, Pityrosporum (1). The skin is also host to a variable number of transient or contaminating bacteria. Although the resident flora produce antibacterial substances that provide some protection against colonization by potential pathogens, any breach in the skin surface, whether accidental or surgical, provides an open door for bacterial infection.

Surgical wound infection rates have been found to vary between 3 and $11 \%$ and wound, skill and burns are areas after genito-urinary tract, where no socomial infections tend to occur more commonly in surgical practice $(2,3,4)$. The risk of infection increase with the degree of contamination and it has been estimated that about $50 \%$ of wound contaminated with bacteria become clinically infected. The prevalent organisms that have been associated with hospital - acquired wound infection include Staphylococcus aureus which from various studies have been found to account for $20-40 \%(3)$, and Pseudomonas aeruginosa $5-15 \%$ of the nosocomial infection, with infection mainly following surgery and burns. Other pathogens such as entercocci and members of he enerobacteriaceae have been implicated, especially in immuno-compromised patients and following abdominal surgery (3).

It is also known that aside surgical units, intensive care units, nurseries, operating room theatre, and recovery rooms are units where nosocomial wound infection frequently occurs $(1,3)$. In the Accident and Emergency unit, accidental wound, clean or dirty, is one of the most common reasons for attendance by patients. In all these units, wound infection which are mainly due to nosocomial pathogens, tends to be associated with bacteraemia, septicaemia, shock and death in some patients, and prolong hospital stay in many others. This situation may be a serious matter for the patient and his family, as his maintenance in the hospital and treatment are expensive and meanwhile a bed space is occupied which might otherwise be used for other patients.

In view of this, there is a need for continuous monitoring of the hospital by infect control team, which should particularly be aware of not only nosocomial wound infection but the local prevalence of antibiotic resistant bacteria strains, as this varies greatly form place to place. The pattern of the bacteria pathogens isolated from wound swabs in thishospital and their antibiotic sensitivity pattern is intended to provide Clinicians and Surgeons valuable information upon which empiric antimicrobial therapy of wound infection can be predicated.

\section{MATERIALS AND METHOD}

This study was carried out over a period of one year (July 2000 - June 2001) at the University of llorin Teaching Hospital, llorin, Nigeria. All wound swabs from different units of the hospital were received on the swab bench 'of the Microbiology laboratory and subjected to routine Gram staining and culture.

Gram staining was done according to the standard techniques (5): Swabs were inoculated onto Blood, Chocolate and MacConkey agar, and plates incubated aerobically at $37^{\circ} \mathrm{C}$ for 24 to 48 hours. Anaerobic culture was not done, as this is not a routine in our laboratory. 
Growth on culture plates were identified by colony morphology, and confirmed by Gram staining reaction, standard biochemical and serological tests(5).

Antibiotic susceptibility of pure culture of confirmed isolates were performed on Diagnostic Sensitivity Test Agar by the Kirby Bauer disc diffusion method (6) using the appropriate Gram positive and Gram negative díscs, and Staphylococcus aureus, Escherichia coli and Pseudomonas aeruginosa as control strains. Isolate was considered sensitive or resistant by comparing zone diameter of inhibition to the zone diameter interpretive standard of the Nationial Committee for Clinical Laboratory Standard (7).

Necessary Patient bio-data were obtained from the laboratory request forms and data were fed into EPI INFO version 6.0 computer with analysis done using the appropriate statistical methods where necessary.

\section{RESULT}

Of all the wound swabs received from 532 patients with clinical evidence of wound infection over the period of study, $346(65 \%)$ were from in-patients, $132 .(24.8 \%)$ from outpatients and $54(10.2 \%)$ were from patients whose wards or clinics were not indicated on the request forms. The distribution of swabs and isolates by wards is shown in Table 1. Surgical wards accounted for the highest number of request and isolation rates, followed by outpatient units and lowest in Psychiatric and Obstetrics and Gynaecology units.

Of the 532 swabs, $444(83.5 \%)$ cultured positive for bacterial pathogens while $88(16.5 \%)$ were bacteriologically sterile. $272(61.5 \%)$ of these yielded single, $152(34.2 \%)$ yielded two while $20(4.5 \%)$ yielded a mixture of three organisms (Table II).

The distribution of bacteria pathogens in pure and mixed cultures is as shown in Tables III and IV. A totel of 642 bacterial isolates were obtained in all, $280(43.6 \%)$ were Gram positive while 362 (56.4\%) we. 2 Gram negative. Staphylococcus auraus was tho predominant organism isolated accounting for $35.3 \%$, followed by Beudomonas spp (21.8\%), Ee herichia coli $(15.3 \%)$, Klebsiella spp (13.4\%), Pruleus spp $(5.6 \%)$, Coagulase Negative S. hylococi $(3.1 \%)$, Sreptococous laecolis (2.8\%), Streptococcus pyogenes $(0.9 \%)$, Group B $\beta$ haemolytic Streptococci $(0.9 \%)$, Acinetobacter spp . $(0.3 \%)$.

The antimicrobial profile of the pathogens is summarized in Table $\mathrm{V}$ and $\mathrm{VI}$. The fluoroquinolones (Ofloxacin, Perfloxacin and Ciprofloxacin) showed increased activity against all the isolates. Cloxacillin, Erythromycin, Gentamicin and Azithromycin equally showed good activity against Staphylococcus aureaus, the predominant Gram positive isolate, with $77.4 \%, 87.8 \%, 93.9 \%$ and $96.5 \%$ of isolates sensitive. Caftazidime is the only Cephalosporin that showed moderate activity against Staphylococcus aureus with $52.2 \%$ of the isolates sensitive. Ampicilin and Penicillin $G$ were ineffective against Staphylococcus aureus with only $18.3 \%$ and $16.5 \%$ of the isolates sensitive, but Streptococcus pyogenes and Group B $\beta$-haemolytic Streptococci are highly sensitive to these agents.

\begin{tabular}{|l|l|l|}
\hline WARDS & SWABS & ISOLATES \\
\hline Surgical (W2, W5, W8) & $168(31.6)$ & $144(32.4)$ \\
Outpatient (SOPMOPIGOP) & $132(24.8)$ & $124(27.9)$ \\
Medical (W1, W4, W6) & $52(9.8)$ & $44(9.9)$ \\
Paediatric (W3) & $52(9.8)$ & $32(7.2)$ \\
Emergency (AVE \& EPU) & $50(9.4$ & $36(8.1)$ \\
Obstetrics and Gynaecology & $12(2.3)$ & $10(2.3)$ \\
Intensive Care Unit & $10(1.9)$ & $8(1.8)$ \\
Psychiatric (W7) & $2(0.4)$ & $2(0.5)$ \\
Not Indicated & $54(10.2)$ & $48(10.8)$ \\
\hline TOTAL & $532(100)$ & $444(100)$ \\
\hline
\end{tabular}

Key:

$W=$ Ward

Number in parenthesis $=$ Percentages

Table 1: Distribution of wound swabs and isolates by wards

\begin{tabular}{|l|l|l|}
\hline Organism & No. & $(\%)$ \\
\hline Staphylococcus aureus & 230 & 35.8 \\
Pseudomonas spp & 140 & 21.8 \\
Escherichia coli & 98 & 15.3 \\
Klebsiella spp & 86 & 13.4 \\
Proteus spp & 36 & 5.6 \\
CONS & 20 & 3.1 \\
Streptococcus faecalis & 18 & 2.8 \\
Group B $\beta$ - haemolytic Strept & 6 & 0.9 \\
Streptococcus Pyogenes & 6 & 0.9 \\
Acinetobacter spp & 2 & 0.3 \\
\hline Total & 642 & $100 \%$ \\
\hline
\end{tabular}

Table 2: Distribution of Bacterial Pathogens lsolated from 44 wounds swabs 


\begin{tabular}{|l|c|l|}
\hline Organism & Number & $(\%)$ \\
\hline Staphylococcus aureus & 116 & $(42.6)$ \\
Pseudomonas spp & 58 & $(21.3)$ \\
Escherichia coli & 46 & $(20)$ \\
Klebsella spp & 24 & $(8.8)$ \\
Coagulase Negative Staphylococci & 12 & $(4.4)$ \\
Proteus spp & 6 & $(2.2)$ \\
Streptococcus pyogenes & 4 & $(1.5)$ \\
Streptococcus faecalis & 4 & $(1.5)$ \\
Group B B-haemolytic streptococci & 2 & $(0.7)$ \\
\hline TOTAL & 272 & $(100)$ \\
\hline
\end{tabular}

Azithromycin, Gentamicin and Caftazidime respectively showed good activity against Pseudomonas spp, the most prevalent Gram negative pathogen, with $60 \%, 64.3 \%$ and $85.7 \%$ of isolates susceptible. Other Gram negative bacteria with the exception of Acinetobacter spp are equally susceptible to these antibiotics.

No in parenthesis $=$ Percentages

Table 3: Distribution of bacteria pathogens from wound swabs in pure cultures

No in parenthesis $=$ Percentages

Table 4: Mixed bacteria growth in wound swabs

\begin{tabular}{|l|l|l|}
\hline ORGANISM & Number & $(\%)$ \\
\hline Staphylococcus aureus, Escherichia coli & 26 & $(15)$ \\
Staphylococcus aureus, Klebsiella spp & 24 & $(14)$ \\
Psedomonas spp, Klebsiella spp & 24 & $(14)$ \\
Staphylococcus aureus, Pseudomonas spp & 22 & $(13)$ \\
Staphylococcus aureus, Proteus spp & 16 & $(9)$ \\
Pseudomonas spp, Escherichia coli & 12 & $(7)$ \\
Staphylococcus aureus, Psedo. spp, Klebsiella spp & 8 & $(5)$ \\
Staphylococcus aureus, Streptococcus faecalis & 4 & $(2)$ \\
Escherichia coli, Coagulase Negative Staphylococci & 4 & $(2)$ \\
Strephylococcus faecalis, Proteus spp, & 4 & $(2)$ \\
Staphylococcus aureus, Proteus spp, Pseudomonas spp & 4 & $(2)$ \\
Staphylococcus aureus, Pseudomonas spp, E. coli & 4 & $(2)$ \\
Pseudomonas spp, Proteus spp & 4 & $(2)$ \\
Pseudomonas spp, Coagulase Negative Staphylococci & 2 & $(1)$ \\
Klébsiella spp, Eshérichia coli & 2 & $(1)$ \\
Klebsiella spp, Proteus spp. & 2 & $(1 !$ \\
Staphylococcus aureus, Streptococcus pyogenes & 2 & $(1)$ \\
Escherichia coli, Streptococcus faecalis & 2 & $(1)$ \\
Acinetobacter spp, Group B Bhaemolytic Streptococi & 2 & $(1)$ \\
Coagulase Negative Stapylococci, Strept. Faecalis & 2 & $(1)$ \\
Pseudo spp, Group B Phaemolytic Strept iKlebs. Spp. & 2 & $(1)$ \\
Streptococcusaecalis, Proteus spp, Pseudomonas spp & 2 & $(1)$ \\
\hline TOTAL & 172 & $(100)$ \\
\hline
\end{tabular}




\begin{tabular}{|c|c|c|c|c|c|}
\hline 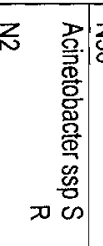 & 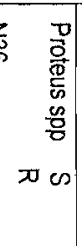 & 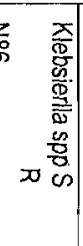 & 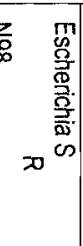 & 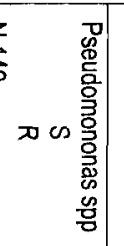 & 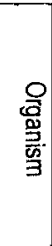 \\
\hline $\begin{array}{l}\text { 숭응 } \\
\text { ㅇㅇㅇ }\end{array}$ & 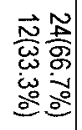 & 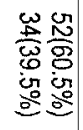 & 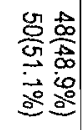 & 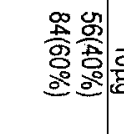 & \\
\hline 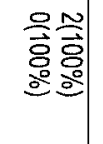 & 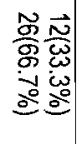 & 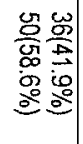 & 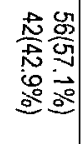 & 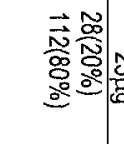 & 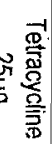 \\
\hline 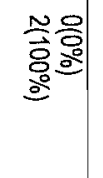 & 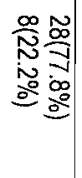 & 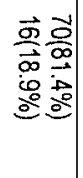 & 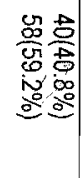 & 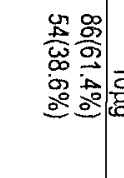 & 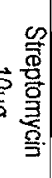 \\
\hline 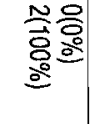 & 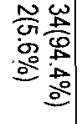 & 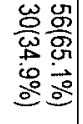 & 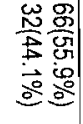 & 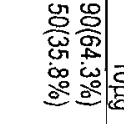 & 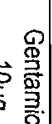 \\
\hline 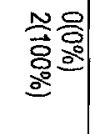 & 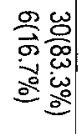 & 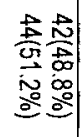 & 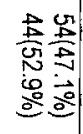 & 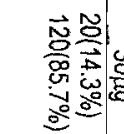 & 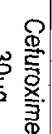 \\
\hline 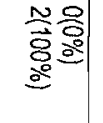 & 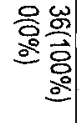 & 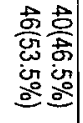 & 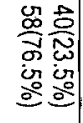 & 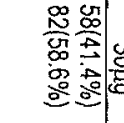 & 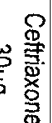 \\
\hline 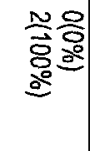 & 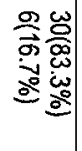 & 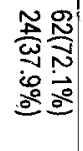 & 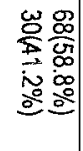 & 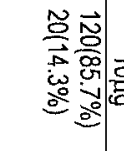 & 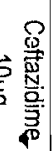 \\
\hline 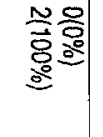 & 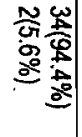 & 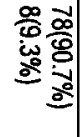 & $\begin{array}{l}\text { No } \\
\text { No } \\
\text { जo } \\
\text { os }\end{array}$ & 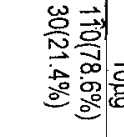 & 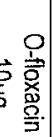 \\
\hline $\begin{array}{l}\text { 능응 } \\
\text { 递 } \\
\text { s. }\end{array}$ & 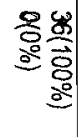 & 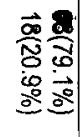 & 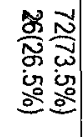 & 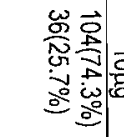 & 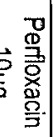 \\
\hline $\begin{array}{l}\text { 동응 } \\
\text { 영 }\end{array}$ & 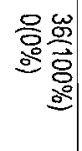 & 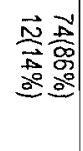 & 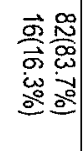 & 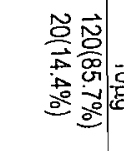 & 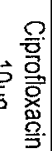 \\
\hline $\begin{array}{l}\text { 응웅 } \\
\text { ㅇㅇㅇ }\end{array}$ & 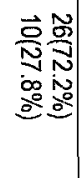 & 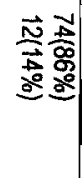 & 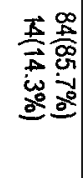 & 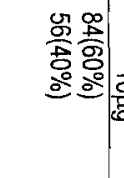 & 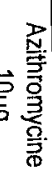 \\
\hline
\end{tabular}

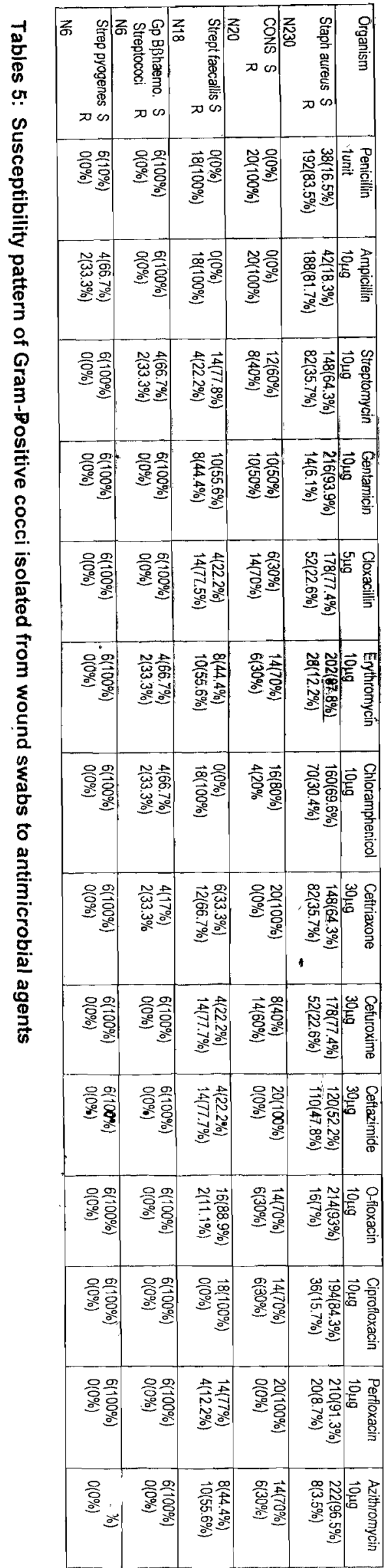




\section{DISCUSSION}

Bacteria contamination of wound is a serious problem in the hospital especially in the surgical practice where clean operations can become contaminated and subsequently infected $(2,8)$. Although it has been argued that wound swabs from surface of intact or ulcerated skin for culture, provides little or no clinically useful information, because of lack of corretation between surface colonization and Below-the-surface infection (9), it is nonetheless known that the degree of wound contamination from surface wounds become clinically infected (2). $83.5 \%$ of wound swabs in this study cultured positive for bacteria pathogens. If $50 \%$ of these were indeed from infected wound, then the wound infection are will be $41.3 \%$. This figure is slightly higher than the $39 \%$ recorded in Lagos (10).

Surgical wards posted the highest number of request and isolation rates of organism. This is in agreement with the trend world wide $(3,8,10,11)$, which is attributable to the fact that patients here are likely to undergo surgical operation, and more likely to have breaks in their local defense systems. The low rate of request and isolation rate in intensive care unit as against the normal trend may be due to the fact that this unit is quite small and requests are therefore correspondingly small. It may also be a reflection of strict hygiene and good nursing practice in this unit.

The common pthogens isolated are Staphylococcus aureus (35.8\%), Pseudomonas spp $(21.8 \%)$, Escherichia coli (15.3\%), Klebsiella spp (13.4\%), Proteus spp (5.6\%), and CONS (3.1\%). The preponderance of Staphylococcus aureus is in keeping with other studies $(3,9,11,12,13)$. The organism is a normal flora of the skin in most people and can easily contaminate wounds. $56.4 \%$ of all isolates are Gram negative organisms against $43.6 \%$ Gram positive bacteria. This is similar to the observation in some other centres (10) where Pseadomonas spp, Klebsiella spp, Escherichia coli and Coliforms are the predominant pathogens responsible for wound and other nosocomial infections. 'This pattern is best understood in terms of selective pressure exerted on the organism based on the current antibiotic use. In our environment, the third generation Caphalosporins are increasingly ssssss being used.

The susceptibility pattern of the organisms heavily favours the Quinolones, particularly Ciprofloxacin, and the new macrolide, Azithromycin, which are effective but expensive antibiotics in the treatment of wound infections in this environment. Ciprofloxacin has to be used with caution in the paedatric age group. In the light of $74.4 \%$ sensitivity of Staphylococcus aureus to Cloxacillin and $87.8 \%$ to Erythromycin, and greater than $60 \%$ sensitivity of the predominant Gram negative organisms to Gentamicin, a cost effective empiric combination of Cloxacillin and Gentamicin or Erythromycin and Gentamicin may be favourably considered for wound infection in this environment.
It is recommended that in addition to using the above antimicrobial theraphy in the treatment of wound infection, adequate attention should be placed on prerentive measures such as hand washing, disinfection, good nursing practice and good surgical techniques amongst others, to reduce bacterial contamination of wounds.

\section{ACKNOWLEDGEMENT}

We are grateful to Miss Fatimah Yusui for typing the manuscript.

\section{REFERENCES}

1. Deurden BI, Reids TMS, Jewsbury JM, rurk DC (eds). A new short textbook of microbial and parasitic infection. Edward Arnold London. 1987.

2. Editorial Nosocomial infections Part II. The Ibadan Surgeons 1992: 19(4): 113-16

3. Balows A, Hausler WJ jr., Hermann RL, et al. (eds). Manual of Clinical Microbiology. $5^{\text {th }}$ edition American Society of Microbiology Press, Washington DC. 1991.

4. Hughes JM, Culver DH, White JW, et al. Nosocomial infections survelliances, 1980-82 morbid, Mortal, Weekly Rep. CDC Surveillance Summaries 1983: 32 (spec. supp 1.4) ISS-16SS.

5. Cheesborough M (ed) Medical Laboratory Manual for Tropical Countries. Vol. II Microbiology Cambridge University Press 1984.

6. Bauer AW, Kirby QMM, Sherris JC et al. Antibiotic susceptibility testing by a standardized single disk method. Am. J. Clin Path 1966; 45: 493-96.

7. National Committee for Clinical Laboratory Standards Performance standards for antimicrobial disk susceptibility tests. NCCLS documents M2-A6, Approved standard $6^{\text {th }}$ edition; Wayne PA: NCCLS 1997.

8. Odelowo EOO, Onile BA Perioperative Infections in Nigerians: A seven year prospective study. E. Afr. Med. J. 1990; 67(3): 172-81.

3. Castiglia M, Smego RA jr. Skin and Soft Tissue infections in: Mahon CR, Manuselis G. (eds) Textbook of Diagnostic Microbiology W.B.Saunders Co. 1995; 97091.

10. Ogunsola FT, Oduyebo O, Iregbu KC, et al. A review of Nosocomial infection at the Lagos University Teaching Hospital: Problems and strategies for improvement J. Nig. Infect. Contr. Ass, 1998; 1(1): 14-20.

11. Ayliffe GAJ, Lowsbury EJI, Geddes AM, Williams JD (eds) control of Hospital Infection (A practice Handbook) $2^{\text {nd }}$ edition Chapman and Hall Medical, London 1992.

12. Dixon RE, effect of infections on Hospital care. Ann. Intern. Med. 1978: 89:749-53.

13. Couper RG, Summer $C$. Hospital infection data from a children's hospital. Med. J. Aust. 1970; 2: 1110-1113. 